\title{
Kritik Retoris: Sebuah Upaya Memahami Teks Alkitab dari Sudut Latar Belakang Retorika
}

Susanto Dwiraharjo

Sekolah Tinggi Teologi Baptis, Jakarta

gitagracia_9903@yahoo.co.id

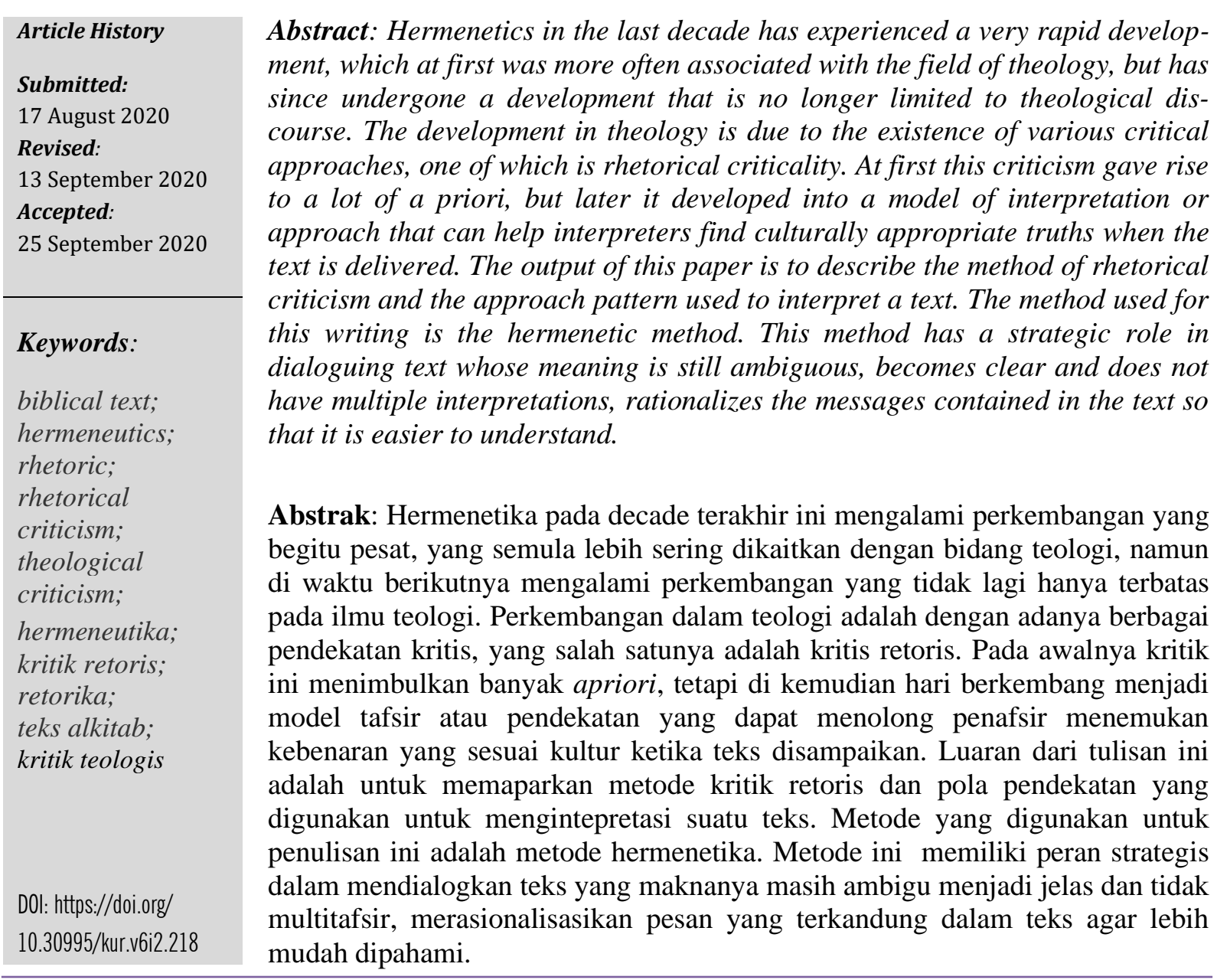

\section{Pendahuluan}

Ilmu hermenetika mengalami perkembangan yang pesat dalam diskursus teologi. Ada berbagai pendekatan yang digunakan dalam rangka memahami teks Alkitab, di antaranya kritik teks, genre, atau redaksi. Masing-masing pendekatan memiliki kelebihan dan kekurangan. Penggunaan berbagai pendekatan ini akan saling melengkapi. Di antara berbagai pendekatan itu muncul pendekatan yang lebih baru di antara semuanya yaitu kritik retoris. Pendekatan ini mencoba melihat latar belakang "retoris" dari masing-masing teks. Rentetan termi- 
nologi Latin yang digunakan dalam analisis retoris cukup dengan sendirinya mencegah sebagian besar penafsir kehilangan pendidikan klasik. Ditambah lagi dengan kesulitan ini, beberapa paparan aplikasi analisis retorik yang ekstrem dalam beberapa kitab Alkitab, dan para penafsir Injili barangkali terhalang untuk menyelidiki alat penafsiran ini. ${ }^{1}$ Dalam studi intepretasi Alkitab, kritik retoris menjadi satu media yang dapat digunakan menemukan kebenaran yang mendalam sesuai dengan maksud teks asli.

Dalam definisi klasik, Aristoteles mendefinisikan retorika sebagai kemampuan menemukan alat-alat persuasi yang tersedia dalam setiap keadaan, fungsi ini hanya dimiliki oleh seni retorika. ${ }^{2}$ Kata "retorika" berasal dari bahasa Yunani "rhetorike", dibentuk dengan menambahkann "ike" yang berarti seni atau ketrampilan. Berikutnya "rhetor," merupakan sebuah istilah yang sering digunakan untuk merujuk pada politisi yang mengajukan mosi di pengadilan atau majelis. Sebagian besar sarjana sepakat bahwa penggunaan istiliah "rhetorike" yang paling awal digunakan oleh Grogias Plato, pada ke-4 SM. Jelaslah praktik pembuatan pidato yang persuasif berasal dari catatan awal sejarah Yunani. Pembuatan pidato adalah aktivitas penting dalam masa Homer. Dengan demikian, praktik "retorika" dalam arti "pidato persuasif" setua sejarah. Mungkin petunjuk yang lebih jelas adalah "oratory," meskipun dalam bahasa Yunan istilah "rhetoreia" muncul sangat terlambat dan jarang digunakan. ${ }^{3}$

Argumentasi epistemologi menyatakan bahwa popularitas retorika dipicu oleh fakta bahwa perspektif retoris menekankan dua atribut manusia sebagai ciptaan yang unik dan sangat penting. Manusia harus berkomunikasi untuk bertahan hidup dalam segala keadaan. Lahirnya studi sistematis menggunakan bahasa untuk mempengaruhi orang lain di Yunani kuno, mau tidak mau secara eksplisit mengakui hal ini. Munculnya retorika modern atau baru di abad dua puluh didasarkan pada dua tesis yang sama, satu linguistik dan yang lain epestemologi, yang bertentangan secara langsung dengan positivisme di awal abad ini. Sekalipun praktik pembuatan pidato diajarkan sebelum Plato, lingkup dan tujuan instruksi tersebut tetap menjadi masalah sengketa ilmiah. Pendidikan yang ditawarkan oleh para sofis yang lebih tua sering disimpulkan dengan istilah "rhetoric," tetapi tidak tampak di antara mereka yang benar-benar menggunakan kata itu, dan M.Gagarin berpendapat bahwa persuasi bukanlah fokus dari pelatihan pendidikan mereka. ${ }^{4}$

Pakar Pendidikan Yunani kuno mengajarkan retorika sebagai bagian dari persiapan orang muda agar cakap berbicara di muka publik, khususnya untuk melatih mereka agar mampu berbicara secara efektif, tokoh penting Yunani seperti Aristoteles, Quintilian, Cicero dll. Menurut Aristoteles ada tiga jenis alat persuasi yang dapat dibuat oleh pembicara. Pertama ditentukan oleh karakter personal pembicara; kedua dengan menempatkan audiens ke dalam kerangka berpikir tertentu; ketiga ditentukan oleh pembuktian atau pembuktian semu

${ }^{1}$ Walter B. Russell, "Rhetorical Analysis Of The Book Of Galatians, Part 1\& 2," Bibliotheca Sacra 150 (1993): 341-358.

${ }^{2}$ Aristoteles, Retorika Seni Berbicara (Yogyakarta: Penerbit Basabasi, 2018), 17.

${ }^{3}$ Ian Worthington, A Companion to Greek Rhetoric (Australia: Blackwell Publishing, 2010), 5.

${ }^{4}$ Ibid. 
yang berasal dari isi pidato itu sendiri. Persuasi berhasil dicapai karakter personal pembicara jika isi pembicaraan sedemikian, hingga membuat pendengar berpikir bahwa pembicara adalah orang yang memiliki kredibilitas. Bagi Aristoteles, retorika terutama merupakan seni persuasi, ia berusaha mengawinkannya dengan filsafat dengan mengklasifikasi retorika berdasarkan ragam aspeknya. Ia mengemukakan tiga tipe pidato; yudisial (legal), deliberative (debat politik atau religius), dan epideitik (pujian atau celaan). ${ }^{5}$

Dalam penggunaannya, perlu membedakan istilah antara kata "retorik" dan "retorikal". Ini diperlukan untuk menentukan berbagai fenomena, seperti pidato, kerangka pidato, genre prosa, bahasa kiasan, kinerja, praktek pedagogis, wacana, strategi penggunaan bahasa, persuasi, dan berbagai teori tentang wacana. Retorika juga dapat didefinisikan sebagai cara untuk berpenampilan. Hasilnya, bahwa segala sesuatu, dan apa pun juga dapat dipelajari sebagai retoris atau retorika. Retorika dalam sejarahnya mengalami perkembangan yang begitu pesat, dan cakupan yang begitu luas, hampir setiap bidang studi dipengaruhi oleh retorika. ${ }^{6}$ Retorika dikembangkan pada zaman Yunani kuno pada abad ke-5 SM ketika Corax dari Syrakusa membuat suatu tulisan yang diberi judul "The Art of Rhetoric" untuk menolong para pemilik property yang terlibat dalam perselisihan hukum atas tanah. Ketika muridnya Tisias memperkenalkan ini di daratan Yunani. Mereka adalah guru-guru profesional yang berjalan berkeliling. Plato (427-347 SM) sendiri bertentangan dengan kaum sofis karena menekankan Teknik melebihi seni dan ucapan persuasif melebihi kebenaran. ${ }^{7}$

Pendekatan secara umum terhadap retorika terjadi sejak Agustinus pertama kali memperkenalkan ke dalam studi Alkitab dalam buku keempat dari karyanya "On Christian Doctrin. Agustinus telah mengajar retorika sebelum bertobat, dan menerapkan pengetahuan itu untuk melukiskan pola retoris atau gaya dalam Kitab Suci. Namun setelah berabad-abad, hanya sedikit karya yang diterbitkan berkenaan dengan retorikat Alkitab. Frase "Rhetorical Criticism" digunakan pertama kali oleh James Muilenberg dalam pesan kepada Society of Biblical Literature di tahun 1968. Muilenberg menantang para ahli untuk melangkah melampaui kritik bentuk dengan memperhatikan dimensi estetik dar gaya literatur dan pola-pola struktural.

Ketika "rhetoric" muncul sebagai kegiatan pendidikan yang diakui, diskrit dan dapat diidentifikasi, istilah ini telah digunakan untuk menunjukkan berbagai praktik dan fungsi wacana. Poin utama adalah agar pembaca mengetahui bahwa setidaknya ada lima cara menggunakan kata "rhetorika" yang disarankan baik oleh para sarjana dulu atau kini: Retorika sebagai contoh pembuatan pidato atau pidato itu sendiri; Retorika sebagai teknik persuasif; Retorika sebagai fungsi taktis dari penggunaan bahasa (retoritas); Retorika sebagai agenda atau program pendidikan yang menanamkan seni atau ketrampilan retorika; Retorika sebagai teori tentang komunikasi manusia. Ruang lingkup retorika, oleh para sarjana diperluas secara luas. Hal itu jika memperhatikan bahwa teks-teks yang secara eksplisit mengidentifikasi diri mereka dengan tradisi retorika,

\footnotetext{
${ }^{5}$ Aristoteles, Retorika Seni Berbicara, 18.

${ }^{6}$ Worthington, A Companion to Greek Rhetoric, 4.

${ }^{7}$ Grant R Osborne, Spiral Hermenetika: Pengantar Komprehensif Bagi Penafsiran Alkitab (Jakarta: Penerbit Momentum, 2016), 159.
} 
dengan menambahkan teks-teks yang diyakini secara implisit berpartisipasi dalam tradisi tersebut. Kemudian setelah mengubah "retorika" menjadi bentuk kata sifat retorikal dan menganggapnya bukan sebagai "sesuatu" tetapi sebagai perspektif atau sudut pandang, maka baik secara eksplisit maupun implisit hal itu dapat menggambarkan apa saja, dan telah menyentuh banyak aspek budaya Yunani. ${ }^{8}$

Tujuan dalam artikel ini adalah, untuk menjelaskan hakikat kritik retoris dan penerapannya dalam praktik interpretasi Alkitab. Arah pembahasan ini dipandu oleh pertanyaan bagaimana kritik retorik menjadi pendekatan alternatif dalam penafsiran Alkitab.

\section{Metode Penelitian}

Tulisan ini merupakan kajian pustaka dengan obyek literatur yang berkenaan dengan kritik retoris. Metode yang digunakan untuk menganalisa topik ini adalah metode kepustakaan. Hal itu dilakukan dengan mengumpulkan data dari berbagai sumber pustaka. Jadi ini sangat terkait dengan pengguna dan layanan Pustaka. Metode ini sangat positif jika digunakan untuk penelitian yang bersifat keagamaan. ${ }^{9}$ Data yang dikumpulkan dari berbagai sumber, kemudian dianalisis dan dikembangkan sebagai bagian dari analisis deskriptif untuk menginterpretasi data yang ada. Di samping sumber utama, untuk melengkapi penulisan ini juga digunakan sumber-sumber acuan. Berbagai data yang terkumpul dianalisis untuk menemukan kebenaran dari topik yang dikaji.

\section{Pembahasan}

Munculnya kritik retoris dalam studi hermenetika memberi pemahaman baru dalam mengintepretasi suatu teks. Para penafisir tidak lagi terpaku pada suatu pola, namun dapat lebih leluasa menggunakan metode dalam menemukan kebenaran dari suatu teks. Hal ini juga menolong para penafsir melihat suatu teks dari beberapa sudut pandang, sehingga kebenaran yang ditemukan akan lebih bersifat komprehensif. Dalam pembahasan ini akan dilihat tentang definisi, posisi dalam studi hermenetika, dan metode kritiknya.

\section{Retorika dalam Studi Hermenetika}

Dalam studi Alkitab, kata "retoris" juga digunakan sebagai sebuah metode penelitian Alkitab atau hermeneutik. Steven Mailloux mengatakan, "Rhetorical hermeneutics attempts to follow out the implications of this last claim by historically situating specific interpretive acts in their particular cultural conversations"10, yang sering disebut sebagai analisa atau kritik retoris. Studi retoris seringkali mempersamakan aspek-aspek formal (genre) dan aspek-aspek fungsional (teknik penataan). Osborne menjelaskan pendapat Cicero terkait dengan pembagian klasik teknik retorika yaitu penemuan, penyusunan gaya dan memori. Bagi studi retoris seperti ini, genre tidaklah penting, karena definisi dari kritik retoris

\footnotetext{
${ }^{8}$ Worthington, A Companion to Greek Rhetoric, 6-7.

${ }^{9}$ Lynn Connaway Silipigni and Ronald R Powel, Basic Research Methods to Librarians (California: Libraries Unlimited, 2007), 5.

${ }^{10}$ Walter Jost and Wendy Olmsted, A Companion to Rhetoric and Rhetorical Criticism (Australia: Blackwell Publishing, 2008), 462.
} 
umumnya hanya memperhatikan proses komunikasi, yaitu teknik-teknik dan pola-pola penataan yang digunakan untuk menghadirkan argumentasi pengarang. ${ }^{11}$

Mack, sebagaimana dikutip oleh Petrus Maryono, menegaskan bahwa retorika itu melibatkan unsur yang lebih luas dari sekedar mencermati dan menggarap unsur artistik, gaya bahasa, dan pemakaian kata-kata indah dan muluk dalam pidato. Kesadaran bahwa retorika pada hakekatnya adalah wujud dari komunikasi, penggunaan retorika yang lebih utama adalah sarana persuasi (bertujuan meyakinkan pendengar) dari sekedar menonjolkan keindahan bahasa (ornamentasi) dalam penuturan ini juga merupakan upaya untuk memahami argumentasi. ${ }^{12}$ Hal ini sesuai dengan hakikat retorika sebagai sarana argumentasi. Ilmu retorika tentu saja berurusan dengan seni berpidato, tetapi tujuan akhirnya bukan sekadar mela-hirkan pembicara yang fasih lidah, meningkatkan kemampuan penutur dalam hal keefektifan. Satu ciri yang juga mewarnai perkembangan kritik retoris adalah adaptasi berbagai teori linguistik modern. Di samping itu, pada dua dasa warsa terakhir ini telah muncul pula sejum-lah model lain yang menandakan bahwa usaha untuk menerapkan kritik retoris dalam studi biblika memang semakin terlihat. ${ }^{13}$

Kritik retoris (rhetorical criticism) merupakan bentuk penulisan yang digunakan dalam analisa struktur, seperti "acts, scenes, episodes, strophes, speeches, discourse. Pesannya merupakan panggilan untuk mempelajari natur dari tradisi penulisan Ibrani sebagai perluasan dari kritik bentuk. Hal ini melibatkan analisa pola struktur dalam suatu unit tulisan dan alat puitis yang menyatukan keseluruhannya. Penekanan sinkronik baru ini terutama sekali memperhatikan masalah struktur dan tekstur. ${ }^{14}$ Penulisan bisa dipecah ke dalam tingkatannya. Analisis tekstur berkaitan dengan pengucapan, suku kata, kata-kata, frasa, kalimat, dan kelompok kalimat. Analisis ini mempelajari pengulangan pikiran, kata-kata kunci, atau motif permainan kata atau paronomasia. Pengulangan bunyi seperti assonance atau alliteration atau adumbration, inclusion, dan sejumlah perlengkapan tulisan lainnya. ${ }^{15}$

Pendekatan terhadap teks sebagai literatur telah membuka penyelidikan bagi para teolog dan juga kritik tulisan. Kritik retoris memampukan teolog mengerti ide teologis dari teks dengan lebih baik, karena analisanya berkaitan dengan bentuk tetap, final dari teks kanon. Jelas bahwa struktur dan tekstur tidak hanya ornamental, namun keduanya adalah cara mengarahkan fokus pembaca pada cerita. Struktur dan tekstur melakukan hal ini secara persuasif dengan membangkitkan respon emosional selain reaksi intektual terhadap cerita. Hal itu memusatkan pikiran dan memberikan kesatuan serta kelanjutan terhadap narasi. Tapi seringkali melakukannya dengan cara yang membuat kesan tak terlupakan pada pembaca, karena elemen yang diulang membawa maju konotasi emosional dan intelektual dari sebelumnya.

\footnotetext{
${ }^{11}$ Osborne, Spiral Hermenetika: Pengantar Komprehensif Bagi Penafsiran Alkitab, 38.

${ }^{12}$ Petrus Maryono, Analisa Retoris: Suatu Teknik Studi Hermeneutik Terhadap Teks Alkitab (Yogyakarta: Penerbit Andi, 2016), 16-17.

${ }^{13}$ Ibid., 17.

${ }^{14}$ Allen Ross, "Rhetorical Criticism," Journal Theology Bibliotheca Sacra (n.d.).

${ }^{15}$ Allen Ross, "Rhetorical Criticism," n.d., Bible.org.
} 


\section{Metode Kritik Retoris}

Metode apa pun bertujuan untuk meminimalkan bahaya. Ada terdapat banyak bahaya ketika penafsir mencoba menggunakan suatu metode penafsiran, hal itu termasuk kritik retoris. Bahaya-bahaya yang terdapaat di dalam kritik retoris itu antara lain: Subyketivisme, memasukkan teori seseorang ke dalam teks; Penerapan dari sarana yang keliru (misalnya memasukkan pola-pola Yunani ke dalam retorika Yahudi); Reduksionisme, terlalu menyederhanakan suatu pola yang rumit; Melebih-lebihkan, berpikir bahwa "kita" mengetahui lebih banyak tentang retorika kuno daripada yang sebenarnya. ${ }^{16}$ Metode ini dibangun di atas dasar semua langkah eksegesis, namun ini bukanlah langkah terakhir dalam proses eksegesis. Strategi retorika yang dipilih akan memiliki dampak hermeneutik bagi penafsiran atas satu perikop. Kritik retoris adalah sebuah metode, sehingga karena itu tidak terlepas dari adanya kelemahan dalam penggunaanya, dan para eksegetor harus mewaspadainya dalam membaca tulisan.

\section{Metode Kritik Retoris dalam Perjanjian Lama}

Metode kritik digunakan untuk memperlihatkan beberapa hal menonjol yang bisa dilakukan, dan juga untuk menambah keingintahuan dalam mempelajarinya. Ini tidak mungkin dilakukan tanpa melihat pada bahasa Ibrani sebagai bahasa asli teks ditulis. Sekalipun itu bukan berarti mengabaikan berbagai varian terjemahan lain. Ini akan lebih jelas apabila melihat pada bahasa asli teks ditulis, secara khusus pada struktur dan teksturnya.

Sekarang ekspositor menghadapi rintangan lain dalam bekerja dengan Alkitab sebagai literatur, satu pemikiran yang ada dalam pemikiran orang Kristen selama ini, yaitu, Alkitab harus ditafsirkan "secara literal." Di dalam penggunaan ide yang terlalu menyederhanakan ini, jika kitab Ayub mengatakan Ayub berkata sesuatu, atau teman-temannya berkata sesuatu maka itulah yang memang mereka katakan. Di sisi lain, banyak penyelidikan tulisan modern melihat isi Alkitab secara berbeda; pada dasarnya mereka melihatnya sebagai suatu karya tulis, dan para penulisnya mampu menggunakan perlengkapan penulisan dalam menceritakan kisah atau menyimpan kata-kata leluhur. Bagi sebagian orang ini artinya cerita-cerita itu dibuat atau dikarang; bagi yang lain itu artinya sebagian kejadian dipergunakan dan dipercantik untuk diceritakan Kembali. ${ }^{17}$

Ada beberapa hal yang perlu dijadikan pertimbangan. Pertama, berapa banyak penafsiran yang diberikan seorang penulis melalui apa yang dia pilih untuk dimasukan atau dikeluarkan dalam melaporkan tradisi? Sebagai contoh, Tawarikh, dengan mengeluarkan narasi mengenai dosa Daud, memberikan suatu gambaran Daud yang berbeda dari kitab Samuel. Kedua, berapa banyak kebebasan yang dimiliki penulis dalam mengatur kembali eksposisi narasi dan dialog untuk membuat suatu puisi seimbang? Sebagai contoh, apakah dialog dalam kitab Ayub aslinya dibawakan dalam 2200 baris puisi Ibrani? Atau, apakah Tuhan memanggil Abram dengan menggunakan puisi klasik Ibrani. Atau, apakah peristiwa dalam kitab Rut memang biasanya mengikuti pola parallel repetition dan inverted repetition. Ketiga, berapa banyak hubungan dari narasi dan penunjukan peristiwa yang diusulkan para penulis kitab melalui pemilihan kata dan frase. Sebagai contoh, apakah Esau benar-benar menggunakan

\footnotetext{
${ }^{16}$ Osborne, Spiral Hermenetika: Pengantar Komprehensif Bagi Penafsiran Alkitab, 163.

${ }^{17}$ Duane F Watson and Allan J. Hauser, Rhetorical Criticism of the Bible (New York: E.J Brill, 1994),
} 
kata "Edom-edom," atau memang narasi memilih menggunakan kata-kata itu untuk menunjukkan natur dari orang Edom? (Kej. 25:29). Atau, apakah Abraham benar-benar memiliki perintah, ketetapan, dan hukum (Kej. 26:6), atau, apakah Musa menggunakan kata-kata itu untuk melihat pemberian Taurat? ${ }^{18}$

Semua itu merupakan bentuk masalah yang akan disaring di kemudian hari, saat berurusan dengan teks. Para ekspositor konservatif biasanya menghrapkan peristiwa-peristiwa dalam Alkitab memang benar-benar terjadi secara esensial, seperti yang dilaporkan; "Esau memang seorang pemburu, dia memang menukarkan hak kesulungannya untuk semangkok makanan, dan Yakub memang membuatnya bersumpah atasnya; Daud memang memerintah sebagai raja, melakukan perzinahan dengan Bethseba, memang memindahkan tabut ke Yerusalem; atau Yesus memang mati di atas salib, memang bangkit dari kematian, memang naik ke sorga." Namun dalam menerima fakta, sarjana konservatif juga perlu memperhatikan seni tulisan yang digunakan dalam teks. Saat digunakan dalam kerangka doktrin inspirasi, seni tulis menambah pengertian dan fokus dari teks. Dalam menggali data historitas peristiwa, seorang penafsir tidak harus mengeluarkan seni tulis dalam menceritakan peristiwa-peristiwa itu, dan analisis terhadap tulisan narasi tidak harus menolak apabila peristiwa faktual sifatnya.

Selama beberapa waktu dianggap bahwa satu alasan adanya seni tulis dalam Alkitab karena materialnya diturunkan secara oral sebelum dituangkan ke dalam tulisan. Pembahasan mengenai tradisi oral sangat penting, dan pelajar harus melihat literatur mengenai hal itu. Bisa saja mengatakan bahwa kemungkinan besar materi itu telah ada dalam bentuk oral, dan karena itu repetisi, khiasme, dan permainan kata telah menjadi penolong dalam mengingat. Tetapi harus dipahami kalau penulisan dengan gaya seperti hal itu sudah umum digunakan di periode awal, dan hal-hal teersebut telah diterapkan dalam penulisan. Barangkali transmisi oral dan penulisan teks telah ada sebanding dan berdampingan di Israel; teks memelihara materinya, dan transmisi oral membantu mengingatnya. ${ }^{19}$

\section{Struktur Teks}

Struktur adalah pengaturan atau organisasi teks. Ini harus dibedakan dari "structuralism" dalam pengertian teknis dari kata itu, karena itu suatu pendekatan yang berbeda yang membawa penelitian ke dimensi yang berbeda. Beberapa pelajar salah dalam menyebutkan kata itu untuk menggambarkan analisa komposisi mereka. Mempelajari struktur dari suatu bagian yang berurusan dengan tingkatan yang lebih tinggi dari suatu karya. Beberapa hal yang digunakan untuk menganalisis struktur, dijelaskan oleh Allen Ross ${ }^{20}$ sebagai berikut:

Perama, Indikator perikop. Umumnya diketahui kalau unit yang ingin dipelajari harus dikenal terlebih dahulu. Ini menuntut usaha keras. Memerlukan banyak waktu untuk mempelajari secara dekat dalam menentukan awal dan akhir perikopnya, serta mencari indikatornya. Setiap unit dari Alkitab seringkali memiliki indikasi yang cukup jelas. Di dalam ucapan para nabi terlihat adanya panggilan berulang dalam bentuk perintah, formulasi pembukaan, atau motif paralel. Di dalam Taurat adalah motif berulang, seperti "I am the

\footnotetext{
${ }^{18}$ Ibid.

${ }^{19}$ Ross, "Rhetorical Criticism."

${ }^{20}$ Ibid.
} 
LORD your God." Di dalam Mazmur dapat ditemukan adanya pola dari tipe mazmur berbeda, dan itu akan membantu dalam membagi satu bagian itu kedalam unit bagian, sekalipun mazmur merupakan suatu unit dasar itu sendiri.

Kedua, Framing atau Inclusio. Perlengkapan lain dari seni tulis adalah framing. Ini berarti menggunakan suatu frasa yang mirip atau identik, motif, atau episode untuk memulai dan mengakhiri unit, atau suatu bagian dari unit. Seperti contoh dalam puisi seperti Mazmur 8. Dalam Mazmur ini frase dimulai dan diakhiri dengan "O LORD, our Lord, how excellent is Your name in all the earth." Hal yang sama juga digunakan dalam penulisan kitab yang lain. Sebagai contoh, didalam Kejadian 9, bagian pertama narasi mengenai perjanjian Nuh, yang menegaskan perintah Allah, "Be fruitful, and multiply, and replenish the earth" (v.1). Perintah ini diulangi sebagian dalam ayat tujuh. Artinya, bagian pertama yang melarang pertumpahan darah, hal ini berarti membunuh, dibingkai (frame) oleh pengulangan perintah untuk menghasilkan hidup. Penulisan yang lebih besar dan rumit juga menggunakan framing. Narasi tentang Yakub bisa menjadi sebuah contoh. Narasi ini terbagi ke dalam lingkaran Yakub-Esau dan lingkaran Yakub-Laban. Lingkaran Yakub-Laban dibingkai (frame) oleh kunjungan Tuhan dimalam hari, pertama di Betel (Kej. 28), ketika itu Yakub sedang meninggalkan tempat kelahirannya, dan kedua di Peniel (Kej. 32), pada saat dia kembali ke rumah kelahirnnya. Penulis berusaha membuat pembacanya menyadari adanya hubungan antara framing dan materi pengahalangnya. Terkadang harus mendekati framing dari dalam narasi.

Ketiga, Kiasme atau Inversi. Kiasme adalah pengaturan materi dalam suatu parallelisme terbalik untuk menunjukan cerminan setengah cerita awal dengan yang selanjutnya, dan untuk menunjukan titik balik dari cerita. Ini merupakan cara menonjol dalam penulisan kritik retoris.

Keempat, Symmetry dan Variasi Urutan. Hal ini berarti penulis menggunakan suatu variasi dari motif dan ekspresi sebelumnya untuk menyejajarkan bagian-bagian dari teks. Ini digunakan untuk menambah pengertian, dan sebagai contoh adalah Kejadian 13. Teks ini merupakan narasi tentang bagaimana Abram menawarkan tanah kepada Lot. Dia meminta agar Lot memilih tanah yang disukainya, dan bagaimana Lot melihat tanah sekitar Yordan, dan pergi ke timur, bermukim disebelah Sodom. Bagian akhir dari pasal itu menyatakan perkataan Tuhan kepada Abraham. Tuhan menyuruh Abram untuk melihat keseluruh arah, karena semuanya itu akan menjadi miliknya. Di sini terlihat jelas, bagaimana penulis membandingkan dua narasi itu untuk menunjukan apa yang dilakukan Lot, Tuhan berikan pada Abraham.

Kelima, Repitisi Motif. Walaupun cara ini bisa diterapkan seperti yang telah disebutkan diatas, hal ini patut dibahas terpisah. Ada saatnya dalam penulisan suatu motif akan muncul berulang-ulang dalam teks, memberi keteraturan terhadap bagian itu. Sebagai contoh, di dalam teks Hukum Tuhan, ungkapan "I am the LORD" ditempatkan untuk menunjukan keteraturan materi. Imamat 19 menunjukkan pembagian struktural ini (atau aslinya) dengan mengulangi ekspresi tertentu. Kelihatannya pasal itu terdiri dari dua bagian, keduanya berisi tanggung jawab sehari-hari. Bagian pertama kelihatannya berisi tanggung jawab terhadap Tuhan (1-10) dan bagian kedua tanggung jawab terhadap manusia (11-37). Enam belas pembagian paragraph ditandai oleh "I am the LORD your God - Akulah Tuhan Allahmu" 
atau "I am the LORD - Akulah Tuhan." Perubahan pertama berhubungan dengan pembagian antara ayat 10 dan 11 .

Keenam, Kutipan-kutipan. Pada inti cerita dalam kitab ada penggunaan kutipan-kutipan baik secara langsung maupun tidak, dan terkadang kutipan-kutipan imaginary (untuk mewakili pemikiran seseorang, atau menjelaskan tindakan seseorang). Kejadian 18:16-33, sebagai contoh, sebagian besar dibangun oleh ucapan-ucapan yang dipisahkan oleh laporan cerita. Ayat 16 melaporkan kalau para malaikat bangkit dan mengarah ke Sodom. Tapi ayat 17-20 kemudian melaporkan suatu soliloquy Ilahi, dan ayat 20-21 suatu ucapan kepada Abraham. Ayat 22 sekali lagi merupakan laporan cerita, memecah ucapan-ucapan: dan lalu berpalinglah orang tersebut dan pergi ke Sodom, tapi Abraham tetap bersama TUHAN. Ayat 23-32 kemudian melaporkan dialog antara Abraham dan TUHAN mengenai penghancuran orang benar bersama dengan orang jahat. Dialog ini dicatat untuk repetisi, repetisi yang penting bagi artinya, karena dia tidak bisa sampai kepada angka terakhir tanpa menguranginya secara perlahan. Cerita itu ditutup dengan laporan lalu TUHAN pergi (v. 33).

Ketujuh, Subordinate Clauses dan Parenthetical Descriptions. Komentar Editorial membentuk bagian penting bagi cerita Ibrani; mereka memberikan penafsiran, penjelasan atau komentar dari penulis. Setiap orang yang terbiasa dengan tulisan kitab Raja-raja dimana penulisnya terus memberitahu pembacanya apakah sang raja berbuat yang benar atau tidak. Hal itu menyediakan informasi bagi pembaca untuk merespon cerita dengan benar. Tetapi, dalam eksegesis terdapat kesempatan parenthetical clause, atau suatu gambaran, memberikan suatu penafsiran yang lebih kabur. Sebagai contoh, saat Lot memilih bermukim di Sodom, cerita itu menjelaskan kejahatan orang Sodom dimata TUHAN" (Gen. 13:12). Dampak dari komentar dari cerita diserahkan kepada pembacanya. Walau hal itu tidak membentuk bagian utama dari struktur sehingga memperluas cerita, tapi berkontribusi terhadap arti. Atau diseluruh karya tulis, seperti kitab Yunus, penulisnya terus menggunakan subordinate clauses untuk memberi arti pada struktur. Jadi, dengan mengerti materi subordinate dan parenthetical bisa memberi kemampuan untuk memisahkan struktur, dan menafsirkannya dengan lebih tepat.

\section{Tekstur Teks}

Tekstur berurusan dengan gaya atau susunan teks. Pekerjaan tingkat yang lebih rendah seperti suku kata, kata-kata, kalimat-semua yang membuat cerita. Hal ini dikerjakan tanpa mengatakan kalau semua hal dalam suatu komposisi itu penting, terutama dalam Alkitab, karena itu hanyalah sebuah seni tulis. Ross dalam Bible.org menjelaskan prinsip-prinsip ini sebagai berikut:

Paronomasia dan Phonetic Word Plays. Melalui perlengkapan ini para penulis menekankan dan menfokuskan perhatian pembaca terhadap maksud penting yang ada dalam teks. Paronomasia adalah suatu permainan kata yang melibatkan suara dan rasa, bagi kata-kata yang digunakan serumpun, sedangkan phonetic word play hanya melibatkan suara. Ada juga beberapa permainan kata yang hanya melibatkan rasa bukan suara. Secara umum, seluruh tipe bisa dikelompokan sebagai permainan kata, dan signifikansinya dalam setiap kasus bisa dijelaskan lebih jauh. Permainan kata biasanya muncul dalam memberi nama cerita dalam 
penulisan cerita, maksud dari permainan kata adalah menekankan arti penting yang ada dalam cerita.

Doubel Etente. Ini adalah kemenduaan teks yang disengaja melalui kata-kata yang memiliki arti ganda. Dalam Kejadian 25:29 arti penting lain bisa terlihat dalam pemilihan kata kerja zid, walau kata itu memang memiliki arti "to boil," kata itu juga digunakan untuk menggambarkan kegiatan mencurigakan (maksud memasak air diujung mewakili seseorang yang melangkahi batas). Jadi konotasi dari kata itu dan suara dari kata itu lebih dari denotasi "boil."

Repetisi. Ini diulangi dalam pengertian yang berbeda. Repetisi ini mengarahkan ekspositor kemaksud dari episode tersebut. Suatu analisa dari kitab Mazmur menunjukan bahwa ini merupakan bagian dari pola pengaturan. Narasi mengenai Yusuf menyatakan bahwa saudarasaudara Yusuf membencinya dan tidak bisa berbicara damai ( $l^{e}$ shalom) padanya (37:4); tapi kemudian bagian berikut dimulai dengan Yakub mengirim Yusuf menemukan keadaan baik ( h $^{e}$ lom) saudara-saudaranya. Penulisan ini telah mempersiapkan pembacanya akan kegagalan misi ini melalui repetisi kata. Terkadang repetisi memakai suatu belitan ironis. Pada Kejadian 12:10-20 kita melihat cerita mengenai penipuan Abram mengenai istrinya Sarai. Pada ayat 13 dia menyuruh istrinya mengatakan kalau dia adalah saudaranya, tapi saat istrinya diambil darinya, teks itu berkata kalau Firaun "memperlakukannya dengan baik."

Allusion dan Foreshadowing. Melalui pemilihan kata yang hati-hati penulis bisa merujuk pada peristiwa sebelumnya (allusions), atau mengantisipasi peristiwa dimasa depan dari sudut pandang teks itu (foreshadowing). Allusion bisa dipengaruhi hanya dengan menggunakan satu kata yang sudah dikenal dengan baik dari konteks lainnya. Pemazmur, para nabi, dan narrator semuanya menggunakan allusions. Pengidentifikasian allusions dibutuhkan agar pembaca atau pendengar bisa terbiasa dengan yang dirujuk.

Notional Features. Ini digunakan pada kalimat-kalimat cerita, terutama melihat latar belakang, rujukan, tindakan, dan ide saat semua itu muncul dalam teks. Hal ini membutuhkan penelitian gramatikal, kosa kata, struktur kalimat, dan pengaturan paragraph. Analisis ini penting karena seringkali ekspositor tidak tahu apa yang ditekankan oleh cerita, terutama jika itu merupakan suatu cerita yang panjang dan berkembang. Ada beberapa proses yang dapat menolong langkah ini. Pertama, mendaftar setiap pribadi, objek dan tempat yang disebutkan dalam cerita (disebut referential taxonomy). Segala hal yang memainkan peran dalam cerita, sehingga tidak ada yang dikeluarkan. Kedua, mendaftarkan setiap cara di mana suatu mahluk, objek atau tempat dirujuk disepanjang teks. Suatu pelajaran mengenai referential variants biasanya untuk menyatakan petunjuk mengenai gaya penulis dan berguna dalam menentukan tema suatu bagian. Ketiga, menentukan apa yang sering digunakan dalam cerita itu (maksudnya, analisis materi secara statistik), membedakan fungsi dari rujukan dalam tata bahasa. Apakah rujukan itu digunakan dalam struktur kalimat utama dari cerita, atau dalam subordinate clauses, atau dalam kutipan? Keempat, membuat suatu ringkasan dari line-event statement dalam teks. Artinya memetik dari teks seluruh pernyataan yang memajukan cerita dalam tindakan dan waktu serta menyatakan kembali semua itu dalam satu daftar terpisah secara berurut sesuai diperkenalkannya mereka kedalam teks. Kelima, memetakan kata-kata kerja dari suatu cerita. Cocokan kata kerja dengan subjeknya. Ini dilakukan untuk melihat 
subjek apa yang paling dinamis dalam cerita. Keenam, menemukan rujukan tematik dalam cerita. Rujukan tematik adalah karakter atau item yang dirujuk lebih dari satu episode dan merupakan subjek dari setidaknya satu baris peristiwa kata kerja.

Adegan. Dalam tulisan narasi, adegan akan terlihat menonjol dalam perkembangan cerita. Ini lebih mudah dikenali melalui perubahan karakter, latar belakang, atau tindakan. Tidak semua memiliki tanda struktural yang jelas seperti yang dimiliki cerita mengenai penciptaan, tapi biasanya cukup jelas untuk mengenali adegan. Di dalam suatu bagian seperti ini analisa subjek dan baris kata kerja utama akan berbeda dari adegan ke adegan, tapi pola paralel antar adegan akan menunjukan penekanan dari narator.

Bahasa Puisi. Didalam mempelajari narasi Ibrani penting untuk mengerti bahasa puisi yang digunakan untuk menangkap maksud dramatisnya. Singkatnya, bahasa kiasan tinggi digunakan untuk mengomunikasikan maksudnya, karena penulis berusaha membuat pembacanya hidup dalam imajinasi cerita itu. Ada saatnya bahasa itu terlihat rahasia karena cukup begitu saja dikatakan untuk menyatakan maksud, dan sisanya diserahkan kepada pembaca untuk diimajinasikan. Bahasa kiasan seperti itu menghidupkan narasi dalam imajinasi dan ingatan pembaca.

\section{Metode Kritik Retoris dalam Perjanjian Baru}

H.D. Betz, sebagaimana dikutip oleh Petrus Maryono, menyatakan bahwa teknis penulisan teks Perjanjian Baru itu dipengaruhi oleh prinsip retorika Yunani. ${ }^{21}$ Menurut Muilenberg, hakekat dokumen biblika sesungguhnya membutuhkan pemakaian teknik tafsir yang memperhitungkan aspek artistik Alkitab, dan salah satu teknik tafsir seperti itu adalah kritik retoris. Dia memperkenalkan jenis kristik retoris, yang fokusnya tertuju pada penyelidikan gaya bahasa dan hal-hal yang sejenis. ${ }^{22}$

Studi kritik retoris Perjanjian Baru utamanya berhubungan dengan rekaman atau catatan retorika atau pidato, bukan penelitian terhadap pidato yang disampaikan di depan pendengar. Ini berarti, penelitian hanya akan terarah pada unsur-unsur penemuan, pengaturan dan gaya bahasa. Pertama, penemuan, ini sangat terkait dengan jenis retorika yang akan digunakan. Jenis-jenis itu adalah yudisial, deliberatif dan epideiktik, dan ini akan mempengaruhi pemilihan materi dan teknik argumentsi. Sebagai contoh, apabila retorika itu berkenaan dengan apa yang akan dilakukan di masa yang akan datang, berarti jenis yang cocok adalah deliberative. Apabila berkenaan dengan masa lalu berarti yudisial, dan epideiktif biasanya digunakan untuk menyatakan teguran atau pujian. Kedua, pengaturan, ini berkenaan dengan cara menyusun materi retorika agar efektif dalam penyampaiannya. Pada tahap ini pembicara memikirkan urutan penyajian terbaik. Pembicara harus memilirkan butir yang perlu atau yang tidak harus dikembangkan lebih lanjut. Ini adalah pendekatan terbaik untuk mengembangkan unit gagasan ke bagian-bagian selanjutnya. Ketiga, gaya bahasa. Ini adalah bagian penting dalam retorika. Pada intinya terdapat tiga model sebagai pilihan, yaitu sederhana, sedang dan anggun. Sederhana berarti pembicara memakai kalimat singkat padat, langsung pada pokok permasalahan, sedikit memakai bahasa kias dan menghindarkan kalimat-kalimat kompleks.

${ }^{21}$ Maryono, Analisa Retoris: Suatu Teknik Studi Hermeneutik Terhadap Teks Alkitab, 13.

${ }^{22}$ Ibid., 16. 
Sedang berarti penggunaan bahasa kiasan cukup banyak, namun pemakaian kalimat komplek dibatasi. Anggun berarti penurut memadati pembicaraan dengan kata-kata dan kalimatkalimat muluk-muluk dan indah serta memanfaatkan bahasa kias sebanyak mungkin. ${ }^{23}$

Sulit untuk mengetahui dengan pasti apakah semua atau sebagian penulis PB telah terlatih dalam ilmu retorika kuno. Retorika secara universal merupakan bagian dari pelatihan Helenistik di tingkat pendidikan lanjutan tingkat atas pada masa itu, dan merupakan subyek penting dari pendidikan sekunder. Terlepas benar atau tidak, Tuhan Yesus, Paulus dan Lukas mendapat pelatihan formal dalam bidang retorika. Karya-karya mereka memperlihatkan suatu pengetahuan yang baik atas Teknik-teknik retorika, dan suatu pendekatan retorika kepada pola-pola persusi di dalam karya-karya PB bisa dibenarkan. Osborne mengutip pendapat Melick mengemukakan tiga asumsi yang dibuat untuk pendekatan ini: Penulis menerapkan teknik-teknik ini secara sadar, artinya banyak dari mereka mendapat pelatihan dalam hal tersebut; Tulisan-tulisan PB pada dasarnya bersifat formal, memanfaatkan gaya Helenistik klasik; Para pembaca asli nyaman dengan hal ini dan memahaminya. ${ }^{24}$

Menerapkan pola retorika klasik itu dapat menolong dalam proses hermeneutik. Hal itu karena dapat membentuk suatu kontrol dengan membandingkan pola-pola dalam Perjanjian Baru. Faktanya, metode inilah yang diterapkan oleh Hans Dieter Betz atas surat Galatia atau studi Duane Watson atas Surat Yudas dan 2 Petrus. Dari karya Hans ini, menurut Osborne dapat diamati bahwa pola retoris memiliki beberapa elemen ${ }^{25}$, yakni: Exordium (Pendahuluan), merupakan pendahuluan yang membangun hubungan antara pembicara dan pendengar dan menciptakan minat untuk serta nama baik bagi subyek yang dibahas; Narratio (Pemaparan), membeberkan proposisi yang sedang dibahas dan menyediakan informasi mengenai latar belakang dan suatu dasar atau alasan bagi pokok yang dibahas; Partition (sering merupakan bagian dari narratio (pemaparan) memberikan secara spesifik pokok pembahasan, seringkali dalam bentuk argument-argumen dari lawan dan juga argumennya sendiri; Probatio atau confirmation (pembuktian), mempresentasikan argumen-argumen logis untuk suatu kasus. Sang pembicara mengatur pembuktian bagi suatu proposisi, mengutip pendapat para ahli dan paralel yang ada untuk memperkuat kasus yang sedang dikembangkan; Refutation (Pertimbangan) seringkali merupakan bagian dari probation. Ini berusaha untuk mematahkan pandangan lawan, biasanya dengan sarana yang serupa dengan probation. Ada kalanya refutation dapat melibatkan suatu digresi (penyimpangan, sering nampak dalam tulisan Paulus) yang menyediakan keterangan tambahan; Peroration atau conclusion (Penutup) adalah kesimpulan, yang merangkum pokok-pokok utama dan mengajukan argumen yang memengaruhi akal dan emosi bagi suatu tesis.

Semua itu hanya merupakan suatu garis besar, para praktisi didorong untuk kreatif dalam penataan dari suatu pidato atau tulisan. Tugas kritik retoris adalah untuk mempelajari suatu unit kuno (misalnya kotbah khusus Tuhan Yesus atau dari Surat-surat), dan melacak argumen yang berkembang agar dapat menentukan pola-pola dari persuasi. Ini merupakan sumbagan berharga bagi tugas eksegesis, karena kritik retoris memberi kemampuan untuk

\footnotetext{
${ }^{23}$ Ibid., 23-26.

${ }^{24}$ Osborne, Spiral Hermenetika: Pengantar Komprehensif Bagi Penafsiran Alkitab, 160.

${ }^{25}$ Ibid., 161-162.
} 
memperhatikan dengan lebih akurat tipe formal dari perikop yang sedang diselidiki. Dalam melakukan analisis retorik ada beberapa prosedur yang perlu diperhatikan.

Pertama, unit retorik. Unit retorika dapat disamakan dengan sebuah perikop. Ini dilakukan untuk melihat bahwa materi yang diselidiki merupakan satu unit retorika yang utuh. Ini juga dapat ditentukan berdasarkan jenis genrenya, namun akan lebih lengkap apabila memakai isi atau gagasan dan argumentasi di dalamnya. Intinya harus memperhatikan unsur awal tengah dan akhir. ${ }^{26}$ Unit retoris harus ditentukan dengan sangat hati-hati, karena ini terkait dengan bagian sebelum dan sesudahnya. Penentuan unit retoris akan memengaruhi hasil akhir dari proses ekssegesis. Unit retoris memiliki pendahuluan, pembahasan dan kesimpulan. Unit retoris dapat berupa unit makro; artinya unit ini perlu dipelajari lebih dahulu pada dirinya sendiri, baru kemudian dipelajari sebagai bagian dari suatu strategi retorika yang lebih besar. ${ }^{27}$

Kedua, situasi retorik. Ini merupakan usaha mencari petunjuk literer dari sekitar konteks, yang dilihat menjadi pemicu munculnya penuturan, dan yang paling penting bagi penafsiran kotbah yang tengah diselidiki. Ini juga berarti bersinggungan dengan stasis dan jenis retorika sebab keduanya sangat lekat dengan situasi retorikal yang akan menjadi arah pengamatan. ${ }^{28}$ Situasi obyektif ketika dilukiskan dalam perikop itu sendiri (biasanya dalam pendahuluan). Situasi subyektif dan dapat diperdebatkan jika situasi tersebut hanya merupakan suatu dugaan dan dapat diperoleh dari tema-tema dalam suatu perikop atau kitab. ${ }^{29}$

Ketiga, jenis retorika. di bagian atas telah disebutkan tiga jenis retorika. Ada tiga tipe, yakni: yudisial, membuat penghakiman atas suatu situasi masa lalu; deliberative, menawarkan nasihat berkenaan dengan kemungkinan situasi di masa depan; epideitik, merayakan atau mengutuk seseorang untuk mencari persetujuan dari pendengar berkenaan dengan suatu nilai tertentu. Watson sebagaimana dikutip oleh Osborne menjelaskan "teori stasis" (status suatu kasus) sebagai sarana untuk menerangkan masalah dengan lebih cermat. Ada tiga stasis; fakta (apakah dia yang melakukan), definisi (apa yang dilakukan) dan kualitas (apakah yang benarbenar dilakukannya). Seorang peneliti harus menentukan beberapa pertanyaan yang perlu dikemukakan dalam suatu perikop dan tipe pertanyaan yang perlu dilibatkan. Seorang pengamat diharapkan dapa melihat dan menentukan jenis retorika yang sedang diselidiki. ${ }^{30}$ Stasis retorika (dapat menyatakan nama dari seseorang, tempat, atau semua benda dan segaa yang dibendakan). Ini berarti seorang pengamat perlu memperhatikan situasi, suasana dan kenyataan dalam peristiwa, agar kebenaran yang sesunguhnya dapat diungkapkan.

Keempat, penataan, teknik dan gaya retorik. Konteks retorika. Menganalisis penataan, teknik dan gaya. Tugasnya bukn hanya menentukan konfigurasi structural dari suatu teks melainkan juga strategi penulis dibalik konfigurasi tersebut. Pengaruh retoris tercipta bukan hanya oleh pemanfaatan bukti-bukti namun dengan cara hal itu ditata. Penataan merupakan satu komponen esensial dari teknik yang digunakan oleh seorang penulis. Gaya bahasa merujuk pada penataan secara artistik dari sarana linguistik untuk meningkatkan pengaruh yang

\footnotetext{
${ }^{26}$ Maryono, Analisa Retoris: Suatu Teknik Studi Hermeneutik Terhadap Teks Alkitab, 49.

${ }^{27}$ Osborne, Spiral Hermenetika: Pengantar Komprehensif Bagi Penafsiran Alkitab, 164.

${ }^{28}$ Maryono, Analisa Retoris: Suatu Teknik Studi Hermeneutik Terhadap Teks Alkitab, 49.

${ }^{29}$ Osborne, Spiral Hermenetika: Pengantar Komprehensif Bagi Penafsiran Alkitab, 164.

${ }^{30}$ Ibid., 165.
} 
dimaksud. Tujuannya untuk memperkenalkan kesenangan, menarik minat dan membujuk pembaca. Ini tidak hanya mencakup sarana-sarana sastra, namun juga susunan dari saranasarana dan kiasan-kiasan tersebut dalam keseluruhan struktur dan argumen yang dikembangkan. $^{31}$

Kelima, mengevaluasi keefektifan retorika. Ini bukan sekedar apakah argument itu baik atau buruk. Ini berarti suatu kritik harus menguji ulang setiap langkah dari proses kritis dan melihat apakah studi yang kritis telah dengan tepat mengevaluasi pendengar, masalah dan sarana retorika yang digunakan seorang penulis mencapai tujuannya. ${ }^{32}$

Singkat kata, kritik retoris harus dimanfaatkan sebagai bagian dari proses eksegesis secara menyeluruh sebagai tujuan dari eksegesis. Sebagai contoh, Walter B. Russell dalam artikel "Rhetorical Analysis of the Book of Galatians" mengulas kitab Galatia menggunakan metode kritik retoris. Analisis retoris menekankan pada dimensi pragmatis teks, sedangkan analisis epistolary berfokus pada bentuk sastra teks. Dalam kitab Galatia sifat retoris lebih jelas dan banyak daripada sifat-sifat epistolary. Artikel itu menjelaskan bahwa 6 langkah prosedur yang diadopsi dan 4 langkah pertama yang didiskusikan.

Pertama, tentukan unit retoris yang akah dipelajari, yang sesuai dalam perikop bentuk retoris (Lebih jelas unit di dalam studi Surat Galatia). Kedua, tetapkan situasi unit retoris. Situasi di Galatia yang menyerukan surat Paulus adalah masuknya ke wilayah guru-guru Kristen Yahudi, tampaknya dari Yerusalem atau di tempat-tempat lain di Yudea, yang menganjurkan model keterikatan bangsa Yahudi yang lama dipegang dengan Israel dengan menjadi penganut agama Yahudi. Barangkali mereka mempertanyakan kepnyaan Paulus kredensial dan naik banding kepada para rasul Yerusalem. Mereka mengajarkan bahwa orang Kristen non-Yahudi harus "di-Yahudikan" jika mereka ingin menjadi bagian dari umat Allah (Gal. 2). Ketiga, tentukan satu masalah retorika utama yang mungkin ada khususnya terlihat pada awal wacana (masalah retoris yang berfungsi sebagai prinsip pengorganisasian bagi orang Galatian ada dua: Paulus menaggapi dua masalah yang diciptakan oleh orang Yudais mengenai identitas orang Galatia dan perilaku mereka sebagai umat Allah). Keempat, tentukan yang mana dari tiga tipe retorika yang unit retorisnya sesuai dengan yudisial, deliberative, epideiktik. (Galatia adalah tipe deliberative karena Paulus berusaha membujuk pendengar untuk membuat keputusan definitif tentang identitas mereka dan perilaku mereka dalam waktu mendatang. Kelima, pertimbangkan pengaturan bahan dalam teks dalam hal sub devisi, efek persuasive dari bagian, koordinasi dan perankat gayanya. Keenam, tinjau ulang proses analisis dengan melihat keseluruhan unit dan keberhasilannya dalam mengatasi situasi retoris dan apa implikasinya bagi pembicara atau pendengar.

Menentukan susunan materi langkah kelima di dalam analisis retoris adalah jelas sangat panjang dan sangat sulit karena itu tergantung pada ketelatenan menganalisis argumentasi di dalam Surat-surat. Tujuan retorika Galatia adalah untuk membujuk orang Galatia menolak Injil palsu kaum Yudais dan melanjutkan yang benar. Paulus telah memberitakan kepada mereka beberapa hal; pertama, naturnya saja sudah dikonfirmasi secara legitimate/sah,

\footnotetext{
${ }^{31}$ Ibid., $165-166$.

${ }^{32}$ Ibid., 166.
} 
sementara Injil palsu kaum Yudais ditolak. Kedua, hal itu telah menempatkan orang Galatia di antara umat Allah yang sejati melalui iman mereka kepada Kristus. Ketiga, hal itu telah memberi mereka pembebasan sejari dari kuasa dosa melalui penerimaan Roh Kudus. Secara lebih spesifik, Russel memberi contoh dari Galatia 1:1-10. ${ }^{33}$ Menurutnya, perikop ini dapat dibagi ke dalam dua bagian; pertama adalah salutation dan kedua prolog.

Pertama, Prescript/Salutation (1:1-5). Sambil mengidentifikasi dirinya (1:1a) dan pengikutnya (1:2a), Paulus memberi nama penerima (1:2b), dan mengucapkan selamat kepada gereja-gereja di Galatia (1:3). Paulus juga memperkenalkan tiga poin utamanya yang kemudian secara berturut-turut dalam tiga bagian utama kirimannya. Sementara semua keseluruhan dari bagian itu adalah salam dari surat dan bukan eksordium formal (pendahuluan pada sebuah pidato), tetap saja memiliki fitur tambahan biasanya ditemukan di dalam eksordium-exordium (atau proem/principium). Fitur-fitur ini adalah tambahan yang tidak biasa dari pernyataan Paulus tentang identitas kerasulan dalam pasal 1:1 dan pernyataannya tentang pembebasan Kristus dalam 1:4. Dalam pengertian ini, salam membuktikan pada tingkat mikro apa yang benar pada tingkat makro dalam kitab Galatia. Paulus mengintegrasikan fitur-fitur eporit dan retoris dalam satu entitas yang baik. Salah satu dari elemen kunci dari intergrasi ini adalah penggunaan Paulus, dari permulaan surat, antitesis, alat retoris. Antithesis terjadi ketika gaya dibangun di atas pertentangan, "kerasulannya melalui Yesus Kristus dan Allah Bapa (1:1).

Fitur-fitur ini adalah tambahan yang tidak biasa dari pernyataan Paulus tentang identitas kerasulan dalam 1:1, dan pernyataannya tentang pembebasan Kristus dalam 1:4. Dalam pengertian ini, salam membuktikan pada tingkat mikro apa yang benar pada tingkat makro Galatia; Paulus mengintegrasikan fitur-fitur eporit dan retorika ke dalam satu entitas. Salah satu elemen kunci dari integritas ini adalah apa yang digunakan Paulus, dari awal surat, antithesis, alat retoris. Antithesis mencakup ketika gaya dibangun di atas pertentangan kerasulannya melalui Yesus Kristus dan Allah Bapa. Ini terbukti di dalam membela kerasulan dan injilnya (1:11-2:21). Allah adalah benar-benar Bapa atas mereka (ditekankan oleh tiga kali pengulangan theou Patro, 1:1, 3-4, yang unik di dalam salam Paulus. 3. Ini dibuktikan dalam pembelaan Paulus akan identitas sejati mereka dalam pasal 3 dan 4. Tuhan Yesus Kristus mati secara subtansial untuk mereka dan hanya itu yang memberi mereka pembebasan dari zaman yang jahat saat ini (1:4-5). Ini terbukti dalam membela pembebasan sejati mereka dari kuasa dosa $(5: 1-6 ; 10){ }^{34}$

Kedua, Prologue, Proem atau Exordium (1:6-10). Paulus menyatakan dua pilihan (Injil) di hadapan orang-orang Galatia dan proposisi umum atau penyebab suratnya (secara progresif ditentukan dalam beberapa argumentasi berikut); untuk membujuk orang Galatia menolak Yudaisme dan melanjutkan di dalam Injil yang benar yang telah dikotbahkan kepada mereka. Sebagaimana telah diamati oleh Betz, ini merupakan contoh insinuation "pendekatan halus" yang dikembangkan oleh para ahli retorika kuno sebagai teknik memperkenalkan masalah retoris yang sulit, "sekarang harus dijelaskan pendekatan, ada tiga kesempatan yang

\footnotetext{
${ }^{33}$ Russell, "Rhetorical Analysis Of The Book Of Galatians, Part 1\& 2."

${ }^{34}$ Ibid.
} 
tidak dapat menggunakan pembukaan langsung, dan ini harus secara hati-hati mempertimbangkannya; pertama, ketika tujuan kita dideskriditkan, yaitu ketika subyek itu sendiri mengasingkan pendengar dari kita. Kedua, ketika pendengar tampaknya telah dimenangkan oleh pembicara sebelumnya. Ketiga, atau ketika pendengar telah menjadi lelah oleh pembicara sebelumnya. ${ }^{35}$

Barangkali, di dalam Galatia kehalusan ini ditemukan di dalam pendahuluan yang diperluas, bukan di dalam exordium. Namun demikian, dalam peraturan lisan gereja-gereja Galatia, salam agaknya berfungsi sebagai exordium dalam sebuah pidato. Paulus sepertinya sadar akan hal ini dan memperkenalkan dalam tema-tema utama Galatia dengan cara yang halus sejak dari awal surat. Dia melakukan hal yang sama di dalam memperluas salam di dalam Rom.1:1-7. Setelah memperkenalkan tema utama dengan penghormatan yang halus di dalam Galatia ini, Paulus kemudian bebas untuk menyatakan proposisinya dalam bagian berikut (Gal. 1:6-10) dalam bahasa langsung yang gamblang. Komunikasi yang terampil dan sensitif seperti itu tidak akan hilang pada budaya pendengar lisan. Untuk mempertahankan penekanan pada oralitas ini, juga menggarisbawahi pentingnya komunikasi lisan karena tingkat melek huruf yang sebelumnya terlalu tinggi di kekaisaran Romawi. Sebagai ganti dari bagian syukur pada adat saat ini, Paulus menyajikan pengantar resmi yang konfrontatif. Ini memiliki karakteristik dan fungsi seperti eksordium retoris atau prolog pidato. ${ }^{36}$

\section{Kesimpulan}

Kritik retoris adalah bagian dari hermenetika. Ini merupakan upaya untuk menemukan kebenaran dari suatu teks dengan sudut pandang yang lain. Pesannya merupakan panggilan untuk mempelajari natur dari tradisi penulisan Ibrani sebagai perluasan dari kritik bentuk, dan melibatkan analisa pola struktur dan alat puitis yang menyatukan keseluruhannya. Metode ini akan menolong para teologi mengerti ide teologis dengan lebih baik, karena analisisnya berkaitan dengan bentuk tetap, final dari teks kanon. Metode ini digunakan untuk meminimalisir bahaya subyektivisme, reduksionisme, dan melebih-lebihkan kebenaran dari suatu teks. Metode ini dibangun di atas dasar semua langkah eksegesis, tetapi bukan langkah terakhir dari proses eksegesis. Para sarjana teologi tidak perlu berapriori terhadap sebuah metode tafsir baru dalam pendekatan biblika; namun, justru sebaliknya, para sarjana teologi perlu mencoba menerapkannya dalam pelaksanaan tafsir Alkitab.

\section{Referensi}

Aristoteles. Retorika Seni Berbicara. Yogyakarta: Penerbit Basabasi, 2018.

Jost, Walter, and Wendy Olmsted. A Companion to Rhetoric and Rhetorical Criticism.

Australia: Blackwell Publishing, 2008.

Maryono, Petrus. Analisa Retoris: Suatu Teknik Studi Hermeneutik Terhadap Teks Alkitab. Yogyakarta: Penerbit Andi, 2016.

Osborne, Grant R. Spiral Hermenetika: Pengantar Komprehensif Bagi Penafsiran Alkitab. Jakarta: Penerbit Momentum, 2016.

Ross, Allen. "Rhetorical Criticism." Journal Theology Bibliotheca Sacra (n.d.). "Rhetorical Criticism," n.d. Bible.org.

\footnotetext{
${ }^{35}$ Watson and Hauser, Rhetorical Criticism of the Bible, 194.

${ }^{36}$ Ibid., 196.
} 
Russell, Walter B. "Rhetorical Analysis Of The Book Of Galatians, Part 1\& 2." Bibliotheca Sacra 150 (1993): 341-358.

Silipigni, Lynn Connaway, and Ronald R Powel. Basic Research Methods to Librarians. California: Libraries Unlimited, 2007.

Watson, Duane F, and Allan J. Hauser. Rhetorical Criticism of the Bible. New York: E.J Brill, 1994.

Worthington, Ian. A Companion to Greek Rhetoric. Australia: Blackwell Publishing, 2010. 